\section{OPTIMUM PERFORMANCE OF GREEN MACHINING ON THIN WALLED TI6AL4V USING RSM AND ANN IN TERMS OF CUTTING FORCE AND SURFACE ROUGHNESS}

\author{
Muhammad Yanisa, Amrifan Saladin Mohrunia*, Safian Sharifb, Irsyadi \\ Yania
}

aMechanical Engineering Department, Sriwijaya University, 30662, Inderalaya, Ogan llir, South Sumatera, Indonesia

bSchool of Mechanical Engineering, Faculty of Engineering, Universiti Teknologi Malaysia, 81310 UTM Johor Bahru, Johor, Malaysia
Article history

Received

25 December 2018

Received in revised form

20 June 2019

Accepted

15 July 2019

Published online

24 October 2019

*Corresponding author mohrunias@unsri.ac.id

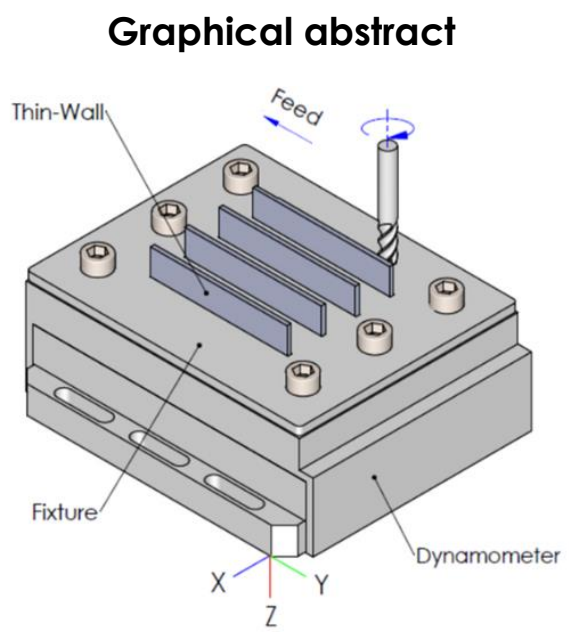

\begin{abstract}
Thin walled titanium alloys are mostly applied in the aerospace industry owing to their favorable characteristic such as high strength-to-weight ratio. Besides vibration, the friction at the cutting zone in milling of thin-walled Ti6Al4V will create inconsistencies in the cutting force and increase the surface roughness. Previous researchers reported the use of vegetable oils in machining metal as an effort towards green machining in reducing the undesirable cutting friction. Machining experiments were conducted under Minimum Quantity Lubrication (MQL) using coconut oil as cutting fluid, which has better oxidative stability than other vegetable oil. Uncoated carbide tools were used in this milling experiment. The influence of cutting speed, feed and depth of cut on cutting force and surface roughness were modeled using response surface methodology (RSM) and artificial neural network (ANN). Experimental machining results indicated that ANN mode prediction was more accurate compared to the RSM model. The maximum cutting force and surface roughness values recorded are $14.89 \mathrm{~N}$, and 0.161 $\mu \mathrm{m}$ under machining conditions of $125 \mathrm{~m} / \mathrm{min}$ cutting speed, $0.04 \mathrm{~mm} /$ tooth feed, $0.25 \mathrm{~mm}$ radial depth of cut (DOC) and $5 \mathrm{~mm}$ axial DOC.
\end{abstract}

Keywords: Optimization, green machining, thin-walled Ti6Al4V, RSM, ANN, cutting force, surface roughness
Abstrak
Kebanyakan aplikasi aloi titanium berketebalan nipis dalam industri aeroangkasa adalah disebabkan kelebihan ciri seperti nisbah kekuatan- terhadap-berat yang tinggi. Di samping getaran, geseran pada zon pemotongan semasa mengisar aloi titanium berketebalan nipis akan menghasilkan ketakkonsistenan/ketaktekalan daya pemotongan dan meningkatkan kekasaran permukaan. Penyelidik terdahulu melaporkan bahawa penggunaan minyak sayuran di dalam pemesinan logam adalah sebagai usaha menuju pemesinan hijau bagi mengurangkan geseran yang tidak diingini. Ujian pemesinan telah dijalankan menggunakan Kuantiti Pelinciran Minimum (MQL) dengan minyak kelapa sebagai cecair pelincir yang mempunyai lebih kesetabilan oksidatif berbanding dengan minyak sayuran yang lain. Mataalat karbida tanpa salutan telah digunakan dalam ujian pemesinan. Pengaruh halaju pemotongan, uluran dan kedalaman 
pemotongan ke atas daya pemotongan dan kekasaran permukaan telah dimodelkan menggunakan RSM dan ANN. Keputusan ujikaji pemesinan menunjukkan ramalan model ANN memberi ketepatan yang lebih baik berbanding dengan model RSM. Daya pemotongan yang maksimum dan nilai kekasaran permukaan yang direkodkan, masing-masing adalah 14.89 $\mathrm{N}$ dan $0.161 \mu \mathrm{m}$ di bawah keadaan pemesinan $125 \mathrm{~m} / \mathrm{min}$ halaju pemotongan, $0.04 \mathrm{~mm} /$ uluran, $0.25 \mathrm{~mm}$ kedalaman pemotongang radia dan $5 \mathrm{~mm}$ kedalaman pemotongan aksial.

Kata kunci: Pengoptimuman, pemesinan hijau, Ti-6Al4V berketebalan nipis, RSM, ANN, daya pemotongan, kekasaran permukaan

(C) 2019 Penerbit UTM Press. All rights reserved

\subsection{INTRODUCTION}

Thin-walled parts are considerably used in many fields of component products such as aerospace, marine, and power industry [1]. Titanium alloys thin-walled in many directions are applied in the aerospace industry owing to their excellent property in the aerospace environment such as light weight, superior resistance to oxidation, lower density, fracture, and fatigue [2], [3]. Ti6Al4V is often used among all titanium alloys because of its high strength, good toughness, and superior resistance to corrosion [2].

During the milling of thin-walled parts, the thin part tends to deform under the action of cutting force [4]. The serrated chips at thin walled caused by elevated cutting zone temperature can significantly promote the formations of built-up edge (BUE) on the tooltip. The presence of BUE will create inconsistent in the cutting force and make surface quality worse [2], [5], [6]. A complex structure of thin-walled and inferior processing technology conduce surface quality challenging to control and give rise to the machining accuracy cannot be guaranteed [4].

The surface roughness mechanism depends on the machining process. The decreased cutting force, which caused the reduced cutting temperature, was generated by the decline of feed rate and cutting speed [7]. Conversely, the decrease in cutting speed improves a surface, not productivity [8]. The combination between restrict the cutting speed and high-efficiency machining should improve the cutting efficiency of machining titanium alloy. Therefore to manage the cutting load is essential to work [2].

Proper comprehensive methods in using cutting fluid may significantly reduce the temperature in machining, and thus, the surface roughness would be better [9]. International Agency for Research on Cancer (IARC) reported that petroleum-based cutting fluids which contain heterocyclic and polyaromatic rings are carcinogenic and could result in occupational skin cancer [8]. It has been reported during the year 1993 that around $16 \%$ of industrial diseases in Finland were caused by cutting fluids. These diseases are connected to the skin and musculoskeletal [10].
Many industries start to concern a cleaner production on their machining process [8]. The objectives in the ISO 14000 family is to preserve the environment in balance with socioeconomic [ 1 1]. These requirements have led to scientific research toward green machining, such as the use of vegetable oil as cutting fluid [8]. Coconut oil has oxidative stability higher than that of other vegetable oils in machining industries [12]. The performance of coconut oil on turning of AISI 304 showed superior surface roughness than soluble oil and straight cutting oil [8]. A study reported sesame and coconut oil with additives in machining AISI 1040 steel, which coconut oil reduced the cutting force by $20 \%$ compared to other considered fluids [6].

The industry is prospecting methods for reducing consumption of cutting fluid during metal cutting operation because of the ecological requirement if using petroleum cutting fluid and economic reason. The high consumption of cutting fluid also results in huge expenses [9]. It is measurable that almost $20-30 \%$ of total industrial costs are related to the using of cutting fluid during hard machining. Minimum quantity lubrication (MQL) apply less cutting fluid, which flows rates ranging from 2 to $14 \mathrm{ml} / \mathrm{h}$ [10]. The increase in $M Q L$ flow rate up to a certain point reduce cutting force. The use of high air pressure in MQL generated the oil droplets which penetrate the cutting zone and decrease cutting energy and friction [5].

Boswell (2017) reviewed many studies about MQL, some of the studies reported about milling of titanium aluminides intermetallic alloy and turning which MQL could lower the surface roughness and cutting force if compared to dry and flood strategy. Muhammed (2016), in his review, recorded that $M Q L$ is comparatively superior to dry and flood at higher cutting speed in machining titanium alloy. The study was written by Vishal (2015) also informed that the influence of MQL conduced reduction in cutting force and surface roughness significantly in milling Ti6Al4V. Drilling Ti6AI4V under MQL using palm oil generated the surface roughness seems to be smoother than that for the MQL synthetic ester during increasing in cutting speed $100 \mathrm{~m} / \mathrm{min}$. However, the increasing feed rate levels bring out to an increase in the surface roughness [13]. Ti6Al4V would harden during milling under MQL 
commercial vegetable oil if cryogenic were applied. Hence the cutting force increased but cutting force decrease if the flow rate of cutting fluid increases [5]. This research intended to investigate the influence of cutting speed, feed rate, and depth of cut on the cutting force and surface roughness in the milling process. The carried out process was milling the thinwalled Ti6Al4V under MQL using uncoated carbide tools. The uncoated WC-Co insert tools are recommended for machining Ti6AI4V [14]. There was research about machining Ti6AI4V by MQL, dry, and flood to analyzed cutting force and surface roughness, which used uncoated carbide insert [11]. Uncoated carbide tools also used in drilling Ti6Al4V under MQL [10]. Gururaj (2017) recorded the using of uncoated carbide tools in the milling of aerospace titanium alloy Ti-6242S under dry cutting condition. Even, uncoated carbide cutting tools used in turning Ti6Al4V under a dry cutting condition at a cutting speed of $150 \mathrm{~m} / \mathrm{min}$ [15].

The influence of cutting load as variable machining of the milling system is uncertain not only came from the use or not use of cutting fluid, but the system is nonlinear behavior [7]. Other problems are conducting experiments time-consuming and prone to error [16]. Therefore, recently, many investigations have focused on the modeled prediction, such as surface topography to optimization machining [3]. RSM, as the mathematical and statistical approach, applies to optimization variables. The coupling method of response surface used in the optimization of cutting force and surface roughness in machining Ti6Al4V under MQL using vegetable oil [11]. ANN methods recorded has been used in the optimization of surface roughness in machining Ti6Al4V under EDM process [17]. This research applied RSM in predicting and optimization of cutting force and surface roughness. RSM methods compared with an artificial neural network (ANN) to investigate the closeness to experiment data.

\subsection{METHODOLOGY}

\subsection{Tool and Material}

The thin wall milling using WC Co uncoated end mill with $10 \mathrm{~mm}, 4$ flute and the helical angle is $47^{\circ}$ (produced by HPMT). The workpiece material used in this experiment was Ti6Al4V grade-5. This material is an aerospace grade commercial titanium alloy. These workpieces were prepared by EDM-Wire Cut and dimension thin wall $3 \times 20 \times 100 \mathrm{~mm}$. Figure 1, as shown workpiece mounted at dynamometer by the specific fixture. Mechanical and chemical properties of the Ti6Al4V is given in Table 1.

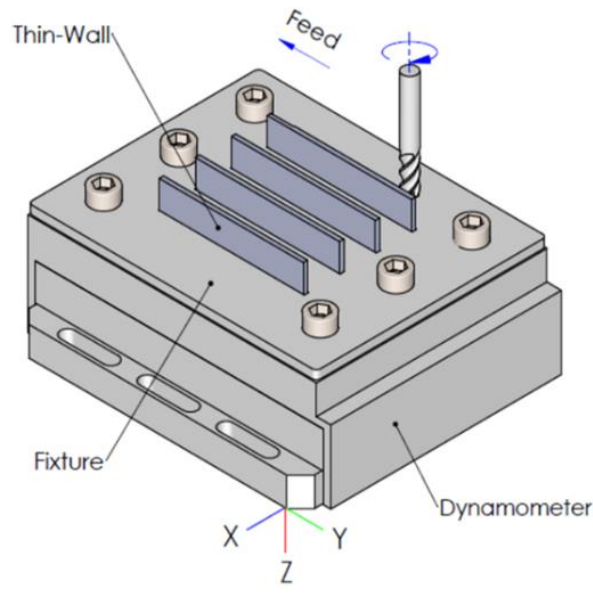

Figure 1 Thin wall fixed on a dynamometer

Table 1 Chemical and mechanic properties of Ti6Al4V

\begin{tabular}{cccccccc}
\hline \multicolumn{7}{c}{ Chemical Composition (wt \%) } \\
\hline Ti & $\mathrm{Al}$ & $\mathrm{V}$ & $\mathrm{C}$ & $\mathrm{Fe}$ & $\mathrm{N}$ & $\mathrm{O}$ & $\mathrm{H}$ \\
\hline Balance & 6.39 & 4.15 & 0.01 & 0.21 & 0.1 & 0.17 & 0.001 \\
\hline \multicolumn{7}{c}{ Mechanical Properties } \\
\hline Tensile Strength & (MPa) & $:$ & & \\
Yield Strength $0.2 \%$ & $(\mathrm{MPa})$ & $:$ & & 840 \\
Elongation & $(\%)$ & $:$ & 15.6 & \\
Reduction of Area & $(\%)$ & $:$ & 38 & \\
\hline
\end{tabular}

\subsection{Cutting Fluid}

The milling experiments used coconut oil as cutting fluids. The cutting fluid was obtained from a local market and locally produced. Cutting fluids as environmentally friendly was operated using the Minimum Quantity Lubrication (MQL) system with a capacity of $40 \mathrm{ml} /$ hour. The specification of the cutting fluid is shown in Table 2.

Table 2 Specifications of coconut oils

\begin{tabular}{ll}
\hline \multicolumn{1}{c}{ Parameters, Unit } & Value \\
\hline 1. Density @ $15^{\circ} \mathrm{C}, \mathrm{kg} / \mathrm{m}^{3}$ & 925.8 \\
2. Flash Point, ${ }^{\circ} \mathrm{C}$ & 286.0 \\
3. Kinematic Viscosity @ $100^{\circ} \mathrm{C}, \mathrm{CSt}$ & 6.069 \\
\hline
\end{tabular}

\subsection{Experimental Setup}

All experiments were performed on a MAHO DMC 835 $\checkmark$ CNC 3 axis VMC with Fanuc Controller model, maximum spindle $14000 \mathrm{rpm}$ and power $15 \mathrm{~kW}$. The Kistler dynamometer (model 9265B) was used for measuring the resultant force (F). During the experiment test, the radial force (x-direction), tangential force (y-direction) and axial force (zdirection) were recorded simultaneously. The analyzed cutting force $\left(F_{c}\right)$ was the tangential force according to the reference system of metal cutting. The resulted surface roughness $\left(R_{a}\right)$ was measured using a surface roughness tester Accretech Handysurf 
type E-35 A/E. The parameters of measurement are 0.8 $\mathrm{mm}$ and $4.0 \mathrm{~mm}$ for cut off (CO) and length of cut (LoC), respectively.

\subsection{Design of Experiments (DOE)}

In this study, the Rotatable Central Composite Design (RCCD) was used. As the independent variables, the cutting speed $\left(V_{c}\right)$, feed rate $\left(f_{z}\right)$, radial DOC $\left(a_{r}\right)$, and axial DOC $\left(a_{x}\right)$ were applied. Whereas, the Ra and the Fc are chosen as dependent variables. The RCCD used consists of the $2^{k}$ factorial design, which is augmented with a star point for each axial coordinate. The distance (a) between the star and center points is equal to 2 [18]. The coded values of every level obtained from Equation 1.

$$
x=\frac{\ln x_{n}-\ln x_{n 0}}{\ln x_{n 1}-\ln n 0}
$$

where $x_{n}$ is the value of any factor corresponding to its natural value, moreover, $x_{n}$ is the value of factor at the level +1 , while the $x_{n o}$ is the natural value of the factor corresponding to the base or level zero. The values in each level were listed in Table 3.

Table 3 The level and coding of independent variables

\begin{tabular}{lccccc}
\hline Independent & \multicolumn{5}{c}{ Levels } \\
\cline { 2 - 6 } Variable & $\mathbf{- 2}$ & $\mathbf{- 1}$ & $\mathbf{0}$ & $\mathbf{+ 1}$ & $\mathbf{+ 2}$ \\
\hline$V_{c}(\mathrm{~m} / \mathrm{min})$ & 64.00 & 80 & 100 & 125 & 156.25 \\
$f_{z}(\mathrm{~mm} /$ tooth $)$ & 0.025 & 0.04 & 0.063 & 0.1 & 0.158 \\
$a_{r}(\mathrm{~mm})$ & 0.200 & 0.25 & 0.32 & 0.4 & 0.51 \\
$a_{x}(\mathrm{~mm})$ & 3.536 & 5 & 7.07 & 10 & 14.17 \\
\hline
\end{tabular}

Data analysis were carried out using RSM and ANN. Many researchers reported that both methods are capable of finding the optimum result [19], [20], [21].

\subsection{Response Surface Methodology (RSM)}

RSM is a statistical procedure, and mathematical modeling used for developing, improving, and optimizing of process. In this experiment, a prediction model for dependent variables can be expressed in Equation 2, and Equation 3.

$$
\begin{gathered}
F_{c}=C_{1} V_{c}^{k} f_{z}^{l} a_{r}^{m} a_{a}^{n} \varepsilon_{1} \\
R_{a}=C_{2} V_{c}^{o} f_{z}^{p} a_{r}^{q} a_{a}^{r} \varepsilon_{2}
\end{gathered}
$$

where $R_{a}$ is the surface roughness, $F_{c}$ is the cutting force, $V_{c}$ is the cutting speed, $f_{z}$ is the feed rate, $a_{r}$ and $a_{x}$ are the radials and axial depth of cut, $\varepsilon$ is the experimental errors, and $C, k, l, m, n$ are the constant of $R_{a}$ and $F_{c}$. The constants of Equation 2 and Equation 3 , were determined by conversion a linear form with a logarithmic transformation, as shown in Equation 4 and Equation 5:

$$
\begin{aligned}
& \ln F_{c}=\ln C_{l}+k \ln V_{c}+\ln f_{z}+m \ln a_{r}+ \\
& n \ln a_{a}+\ln \varepsilon_{l} \\
& \ln R_{a}=\ln C_{2}+o \ln V_{c}+p \ln f_{z}+q \ln a_{r}+ \\
& r \ln a_{a}+\ln \varepsilon_{2}
\end{aligned}
$$

The linear model of Equation 5 and Equation 6 are described as Equation 6 below:

$$
y=\beta_{0}+\beta_{1} x_{1}+\beta_{2} x_{2}+\beta_{3} x_{3}+\beta_{4} x_{4}
$$

where $y$ is the $R_{a}$ or $F_{c}$ response on a logarithmic scale, $x_{1}$ to $x_{4}$ is the logarithmic transformation of independent variables, and $\beta_{0}$ to $\beta_{4}$ are the regression coefficients to be estimated. Equation 6 can be rewritten as Equation 7:

$$
\hat{y}=y-\varepsilon=b_{0}+b_{1} x_{1}+b_{2} x_{2}+b_{3} x_{3}+b_{4} x_{4}
$$

where, $\hat{y}_{1}$ is the determined response, $\varepsilon$ is the experiment error, $b_{1}$ to $b_{4}$ are the estimated value of $\beta_{0}$ to $\beta_{4}$. The quadratic model $\hat{y}_{2}$ can be extended as Equation 8:

$$
\begin{aligned}
y=y-\varepsilon= & b_{0}+b_{1} x_{1}+b_{2} x_{2}+b_{3} x_{3}+b_{4} x_{4}+ \\
& b_{12} x_{1} x_{2}+b_{13} x_{1} x_{3}+b_{14} x_{1} x_{4}+b_{23} x_{2} x_{3} \\
& +b_{24} x_{2} x_{4}+b_{34} x_{3} x_{4}+b_{11} x_{1}^{2}+b_{22} x_{2}^{2} \\
& +b_{33} x_{3}^{2}+b_{44} x_{4}
\end{aligned}
$$

To determine the linear quadratic and relationship component of the response using an analysis of variance (ANOVA) method.

\subsection{Artificial Neural Networks (ANN)}

An ANN is a model for predicting response parameters (dependent variable) using the same principles as biological neural systems. It's one of the most proper analyses in artificial intelligence (Al). ANN can be effectively used to determine the input-output relationship of a complicated process and is considered as a tool in nonlinear statistical data modeling. The ANN structure is built with several neurons on the input layer, hidden layer, and output layer.

The information has processed the neuron and is propagated to other neurons through the synaptic weight of the links connecting the neuron ( $\left.W_{i}\right)$. Summation the weight input to neurons and including bias is given in Equation 9 [20], [19].

$$
y=f\left(\sum_{i=0}^{n} w_{i} x_{i}+\theta\right)
$$

where, $x_{i}$ is the input data, and $\theta$ is the bias of the hidden layer. The weighted output is passed-through- 
activation-function. The activation functions are used in the hidden and output layer to choose the best activation function that gives the minimum error at output layers during training and testing data. The activation functions are using tansig, logsig, or purelin.

The optimal network configuration during training and testing are found through the calculation of statistical error and commonly are used a function such as Mean Square Error (MSE) and Mean Absolute Percentage Error (MAPE), etc. The error functions are defined by Equation 10 and Equation 11.

$$
\begin{aligned}
& \text { MSE }=\left(\frac{1}{N}\right) \sum_{N=1}^{N}\left(\left|t_{i}-O_{i}\right|\right)^{2} \\
& \text { MAPE }=\left(\frac{1}{N}\right) \sum_{N=1}^{N}\left|\frac{t_{i}-O_{i}}{O_{i}}\right|
\end{aligned}
$$

where $t$ is the target value, $O$ is the output value, and $N$ is the number of experiments.

\subsection{RESULTS AND DISCUSSION}

Surface roughness and cutting force $\left(F_{c}\right)$ results are shown in Table 4. The prediction model using RSM by utilizing the Design Expert 10.0 and ANN by Matlab 14a software.

\begin{tabular}{|c|c|c|c|c|c|c|c|}
\hline \multirow{2}{*}{$\begin{array}{l}\text { Std. } \\
\text { Order }\end{array}$} & \multirow[t]{2}{*}{ Type } & \multicolumn{4}{|c|}{$\begin{array}{l}\text { Levels of input factor } \\
\text { (coded) }\end{array}$} & \multirow{2}{*}{$\begin{array}{c}\text { Cutting } \\
\text { Force } \\
\text { Fc (N) }\end{array}$} & \multirow{2}{*}{$\begin{array}{c}\text { Surface } \\
\text { Roughness } \\
R_{a}(\mu \mathrm{m})\end{array}$} \\
\hline & & $V_{c}$ & $f_{z}$ & $a_{r}$ & $a_{x}$ & & \\
\hline 1 & \multirow{16}{*}{ 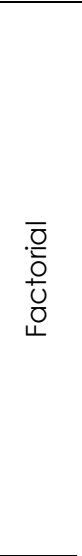 } & -1 & -1 & -1 & -1 & 20.689 & 0.223 \\
\hline 2 & & 1 & -1 & -1 & -1 & 13.983 & 0.187 \\
\hline 3 & & -1 & 1 & -1 & -1 & 20.614 & 0.283 \\
\hline 4 & & 1 & 1 & 1 & -1 & 25.616 & 0.183 \\
\hline 5 & & -1 & -1 & 1 & -1 & 25.085 & 0.190 \\
\hline 6 & & 1 & -1 & 1 & -1 & 22.916 & 0.176 \\
\hline 7 & & -1 & 1 & 1 & -1 & 36.112 & 0.255 \\
\hline 8 & & 1 & 1 & 1 & -1 & 39.173 & 0.270 \\
\hline 9 & & -1 & -1 & -1 & 1 & 29.798 & 0.187 \\
\hline 10 & & 1 & -1 & -1 & 1 & 31.244 & 0.190 \\
\hline 11 & & -1 & 1 & -1 & 1 & 46.511 & 0.297 \\
\hline 12 & & 1 & 1 & -1 & 1 & 51.180 & 0.260 \\
\hline 13 & & -1 & -1 & 1 & 1 & 48.152 & 0.220 \\
\hline 14 & & 1 & -1 & 1 & 1 & 41.959 & 0.220 \\
\hline 15 & & -1 & 1 & 1 & 1 & 61.658 & 0.238 \\
\hline 16 & & 1 & 1 & 1 & 1 & 71.003 & 0.307 \\
\hline 17 & \multirow{8}{*}{$\frac{\overline{0}}{\bar{x}}$} & -2 & 0 & 0 & 0 & 34.918 & 0.282 \\
\hline 18 & & 2 & 0 & 0 & 0 & 34.050 & 0.223 \\
\hline 19 & & 0 & -2 & 0 & 0 & 20.478 & 0.120 \\
\hline 20 & & 0 & 2 & 0 & 0 & 54.520 & 0.288 \\
\hline 21 & & 0 & 0 & -2 & 0 & 24.415 & 0.195 \\
\hline 22 & & 0 & 0 & 2 & 0 & 53.338 & 0.275 \\
\hline 23 & & 0 & 0 & 0 & -2 & 17.439 & 0.235 \\
\hline 24 & & 0 & 0 & 0 & 2 & 66.817 & 0.253 \\
\hline 25 & \multirow{6}{*}{ 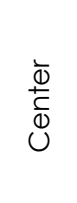 } & 0 & 0 & 0 & 0 & 33.707 & 0.220 \\
\hline 26 & & 0 & 0 & 0 & 0 & 29.288 & 0.238 \\
\hline 27 & & 0 & 0 & 0 & 0 & 31.062 & 0.212 \\
\hline 28 & & 0 & 0 & 0 & 0 & 31.204 & 0.256 \\
\hline 29 & & 0 & 0 & 0 & 0 & 30.240 & 0.273 \\
\hline 30 & & 0 & 0 & 0 & 0 & 31.762 & 0.228 \\
\hline
\end{tabular}

Table 4 Independent variable and experiment results
The machining force used for analysis is Fc (mean cutting force) that is perpendicular to the thin wall surface. The average arithmetic surface roughness $\left(R_{a}\right)$ is used to measure surface quality, and measurements are made at three times at the end of each workpiece.

\subsection{Modelling by RSM}

Analysis of variance (ANOVA) is used to analyze the effect of each parameter of Surface roughness and cutting force. The study was set at a significance level as $5 \%$ and a confidence level at $95 \%$. Table 5 and Table 6 give the ANOVA result on cutting force and surface roughness of the first order.

Table 5 ANOVA for response surface linear model on cutting force

\begin{tabular}{lrrrrrr}
\hline Source & $\begin{array}{c}\text { Sum of } \\
\text { Squares }\end{array}$ & df & $\begin{array}{c}\text { Mean } \\
\text { Square }\end{array}$ & F-Value & $\begin{array}{c}\text { P-value } \\
\text { Prob }>F\end{array}$ & Remarks \\
\hline Model & 4.51 & 4 & 1.13 & 126.96 & $<0.0001$ & significant \\
A-Vc & 0.0003 & 1 & 0.0003 & 0.0359 & 0.8512 & \\
B-fz & 1.11 & 1 & 1.11 & 125.67 & $<0.0001$ \\
C-DOC & 0.8890 & 1 & 0.8890 & 100.20 & $<0.0001$ \\
Rad & & & & & & \\
\hline D-DOC & 2.50 & 1 & 2.50 & 281.93 & $<0.0001$ \\
Ax & & & & & \\
Residual & 0.2218 & 25 & 0.0089 & & \\
Lack of Fit & 0.2105 & 20 & 0.0105 & 4.66 & 0.0477 significant \\
$\begin{array}{l}\text { Pure Error } \\
0.0113\end{array}$ & 5 & 0.0023 & & \\
Cor Total & 4.73 & 29 & & &
\end{tabular}

Table 6 ANOVA for response surface linear model on surface

\begin{tabular}{|c|c|c|c|c|c|c|}
\hline Source & $\begin{array}{l}\text { Sum of } \\
\text { Squares }\end{array}$ & df & $\begin{array}{c}\text { Mean } \\
\text { Square }\end{array}$ & F-Value & $\begin{array}{l}\text { P-value } \\
\text { Prob }>F\end{array}$ & Remarks \\
\hline Model & 0.7351 & 4 & 0.1838 & 10.65 & $<0.0001$ & significant \\
\hline$A-V_{C}$ & 0.0387 & 1 & 0.0387 & 2.24 & 0.1468 & \\
\hline$B-f z$ & 0.6266 & 1 & 0.6266 & 36.32 & $<0.0001$ & \\
\hline $\begin{array}{l}\text { C-DOC } \\
\text { Rad }\end{array}$ & 0.0421 & 1 & 0.0421 & 2.44 & 0.1307 & \\
\hline $\begin{array}{l}\text { D-DOC } \\
A x\end{array}$ & 0.0278 & 1 & 0.0278 & 1.61 & 0.2163 & \\
\hline Residual & 0.4313 & 25 & 0.0173 & & & \\
\hline Lack of Fit & 0.3858 & 20 & 0.0193 & 2.12 & 0.2066 & $\begin{array}{l}\text { not } \\
\text { significant }\end{array}$ \\
\hline Pure Error & 0.0454 & 5 & 0.0091 & & & \\
\hline Cor Total & 1.17 & 29 & & & & \\
\hline
\end{tabular}
roughness

The first order model in term of coded factors, as follows in Equation 12 and Equation 13:

$$
\begin{aligned}
& \ln F_{c}=3.5-0.0036 x_{1}+0.2155 x_{2}+ \\
& 0.1925 x_{3}+0.3228 x_{4} \\
& \ln R_{a}=-1.44-0.0401 x_{1}+0.1616 x_{2}+ \\
& 0.0419 x_{3}+0.034 x_{4}
\end{aligned}
$$


By substituting Equation 12 and Equation 13 to Equation 1, the transformed equation of Ra and FC prediction is given Equation 14 and Equation 15.

$$
\begin{aligned}
& F_{a}=56.023 V_{c}^{-0.0161} f_{z}^{0.4665} a_{r}^{0.8627} a_{a}^{0.9311} \\
& R_{a}=1.4003 V_{c}^{-0.1797} f_{z}^{0.3498} a_{r}^{0.1878} a_{a}^{0.0981}
\end{aligned}
$$

From Table 5 and Table 6, it is evident that Lack of Fit (LoF) for Ra was not significant, but LoF the Fc was contrary. Therefore, only the Ra was well modeled to first order model. In this study, the second order model was used to developed and nonlinear prediction curve. The adequacy and fitness of the model for the second order are shown in Table 7 and Table 8.

Table 7 ANOVA for response surface quadratic model on cutting force

\begin{tabular}{lrrrrrr}
\hline Source & $\begin{array}{c}\text { Sum of } \\
\text { Squares }\end{array}$ & df & $\begin{array}{c}\text { Mean } \\
\text { Square }\end{array}$ & F-Value & $\begin{array}{r}\text { P-value } \\
\text { Prob>F }\end{array}$ & Remarks \\
\hline Model & 4.64 & 14 & 0.3311 & 54.04 & $<0.0001$ & significant \\
A-VC & 0.0003 & 1 & 0.0003 & 0.0520 & 0.8227 & \\
B-fz & 1.11 & 1 & 1.11 & 181.98 & $<0.0001$ & \\
C-DOC & 0.8890 & 1 & 0.8890 & 45.11 & $<0.0001$ \\
Rad & & & & & & \\
D-DOC & 2.50 & 1 & 2.50 & 408.26 & $<0.0001$ \\
Ax & & & & & & \\
AB & 0.0767 & 1 & 0.0767 & 12.52 & 0.0030 \\
AC & 0.0000 & 1 & 0.0000 & 0.0068 & 0.9353 \\
AD & 0.0068 & 1 & 0.0068 & 1.11 & 0.3084 \\
BC & 0.0011 & 1 & 0.0011 & 0.1812 & 0.6764 \\
BD & 0.0028 & 1 & 0.0028 & 0.4490 & 0.5130 \\
CD & 0.0052 & 1 & 0.0052 & 0.8462 & 0.3722 \\
A 2 & 0.0108 & 1 & 0.0108 & 1.76 & 0.2043 \\
B2 & 0.0039 & 1 & 0.0039 & 0.6415 & 0.4357 \\
C2 & 0.0267 & 1 & 0.0267 & 4.36 & 0.0542 \\
D2 & 0.0082 & 1 & 0.0082 & 1.34 & 0.2648 \\
Residual & 0.0919 & 15 & 0.0061 & &
\end{tabular}

Table 8 ANOVA for response surface quadratic model on surface roughness

\begin{tabular}{|c|c|c|c|c|c|c|}
\hline Source & $\begin{array}{l}\text { Sum of } \\
\text { Squares }\end{array}$ & df & $\begin{array}{l}\text { Mean } \\
\text { Square }\end{array}$ & F-Value & $\begin{array}{c}\text { P-value } \\
\text { Prob }>F\end{array}$ & Remarks \\
\hline$B C$ & 0.0012 & 1 & 0.0012 & 0.0895 & 0.7689 & \\
\hline $\mathrm{BD}$ & 0.0039 & 1 & 0.0039 & 0.2794 & 0.6048 & \\
\hline$C D$ & 0.0023 & 1 & 0.0023 & 0.1620 & 0.6930 & \\
\hline$A^{2}$ & 0.0056 & 1 & 0.0056 & 0.4005 & 0.5364 & \\
\hline $\mathrm{B}^{2}$ & 0.1007 & 1 & 0.1007 & 7.24 & 0.0168 & \\
\hline$C^{2}$ & 0.0009 & 1 & 0.0009 & 0.0633 & 0.8047 & \\
\hline$D^{2}$ & 0.0014 & 1 & 0.0014 & 0.1033 & 0.7524 & \\
\hline Residual & 0.2086 & 15 & 0.0139 & & & \\
\hline Lack of Fit & $\dagger 0.1631$ & 10 & 0.0163 & 1.80 & 0.2690 & $\begin{array}{l}\text { not } \\
\text { significant }\end{array}$ \\
\hline Pure Error & 0.0454 & 5 & 0.0091 & & & \\
\hline Cor Total & 1.17 & 29 & & & & \\
\hline
\end{tabular}

\begin{tabular}{lccccccc}
\hline Source & $\begin{array}{c}\text { Sum of } \\
\text { Squares }\end{array}$ & df & $\begin{array}{c}\text { Mean } \\
\text { Square }\end{array}$ & F-Value & $\begin{array}{c}\text { P-value } \\
\text { Prob>F }\end{array}$ & Remarks \\
\hline Model & 0.9578 & 14 & 0.0684 & 4.92 & 0.0020 & significant \\
A-VC & 0.0387 & 1 & 0.0387 & 2.78 & 0.1161 & \\
B-fz & 0.6266 & 1 & 0.6266 & 45.07 & $<0.0001$ & \\
C-DOC & 0.0421 & 1 & 0.0421 & 3.03 & 01023 & \\
Rad & & & & & & \\
D-DOC & 0.0278 & 1 & 0.0278 & 2.00 & 0.1781 \\
Ax & & & & & & & \\
AB & 0.0000 & 1 & 0.0000 & 0.0019 & 0.9658 \\
AC & 0.0581 & 1 & 0.0581 & 4.18 & 0.0589 \\
AD & 0.0369 & 1 & 0.0369 & 2.66 & 0.1239 \\
\hline
\end{tabular}

From the ANOVA analysis, the model F-value of the Fc was 54.04, and Ra was 4.92. It was implied that the model was significant. The LoF value of 3.57 and 1.8 indicated that LoF was not significant. Therefore, the second order model was chosen to develop the models. And equation in term of coded factors as follows in Equation 16 and Equation 17.

$$
\begin{aligned}
& \ln F_{C}=3.5-0.0036 x_{1}+0.2155 x_{2}+ \\
& 0.1925 x_{3}+0.3228 x_{4}+0.0692 x_{1} x_{2}+ \\
& 0.0016 x_{1} x_{3}+0.0206 x_{1} x_{4}+0.0083 x_{2} x_{3}+ \\
& 0.0131 x_{2} x_{4}-0.0180 x_{3} x_{4}+0.0198 x_{1}^{2}+ \\
& 0.0120 x_{2}^{2}+0.312 x_{3}^{2}+0.0173 x_{4}^{2} \\
& \ln R_{a}=-1.44-0.0401 x_{1}+0.1616 x_{2}+ \\
& 0.0419 x_{3}+0.034 x_{4}-0.0013 x_{1} x_{2}+ \\
& 0.0603 x_{1} x_{3}+0.0481 x_{1} x_{4}+0.0088 x_{2} x_{3}+ \\
& 0.0156 x_{2} x_{4}+0.0119 x_{3} x_{4}+0.0142 x_{1}^{2}- \\
& 0.0606 x_{2}^{2}-0.0057 x_{3}^{2}+0.0072 x_{4}^{2}
\end{aligned}
$$

Based on the second order Ra and Fc model, the optimization condition was to be investigated. The optimization was determined on the minimum value of $F_{c}$ and $R_{a}$. RSM optimization results are shown in Table 9 and Table 10. Optimum cutting parameter were $V_{c}=125 \mathrm{~m} / \mathrm{min}, f_{z}=0.04 \mathrm{~mm} /$ tooth, $a_{r}=0.25 \mathrm{~mm}$ and $a_{a}=5 \mathrm{~mm}$. Optimum parameters resulted in Ra and Fc were $14.89 \mathrm{~N}$ and $0.161 \mu \mathrm{m}$, respectively.

Table 9 Optimum machining parameters for cutting force

\begin{tabular}{cccccccc}
\hline $\begin{array}{c}\text { Num } \\
\text { ber }\end{array}$ & $V_{c}$ & $f_{z}$ & $\begin{array}{c}\text { DOC } \\
\text { Rad }\end{array}$ & $\begin{array}{c}\text { DOC } \\
\text { Ax }\end{array}$ & Fc & Desirability & \\
\hline $\mathbf{1}$ & $\mathbf{1 2 5 . 0 0}$ & $\mathbf{0 . 0 4 0}$ & $\mathbf{0 . 2 5}$ & $\mathbf{5 . 0}$ & $\mathbf{1 4 . 8 9}$ & $\mathbf{0 . 9 8 4}$ & Selected \\
2 & 124.49 & 0.040 & 0.25 & 5.0 & 14.93 & 0.983 & \\
3 & 124.10 & 0.040 & 0.25 & 5.0 & 14.93 & 0.983 & \\
$\ldots$ & $\ldots$ & $\ldots$ & $\ldots$ & $\ldots$ & $\ldots$ & $\ldots$ & \\
\hline
\end{tabular}


Table 10 Optimum machining parameters for surface roughness

\begin{tabular}{cccccccc}
\hline $\begin{array}{c}\text { Num } \\
\text { ber }\end{array}$ & $\mathbf{V}_{\mathbf{c}}$ & $\mathbf{f}_{\mathbf{z}}$ & $\begin{array}{c}\text { DOC } \\
\text { Rad }\end{array}$ & $\begin{array}{c}\text { DOC } \\
\text { Ax }\end{array}$ & $\mathbf{R}_{\mathbf{a}}$ & Desirability & \\
\hline $\mathbf{1}$ & $\mathbf{1 2 5 . 0 0}$ & $\mathbf{0 . 0 4 0}$ & $\mathbf{0 . 2 5}$ & $\mathbf{5 . 0 0}$ & $\mathbf{0 . 1 6 1}$ & $\mathbf{0 . 7 8 1}$ & Selected \\
2 & 124.99 & 0.040 & 0.25 & 5.03 & 0.161 & 0.779 & \\
3 & 124.99 & 0.040 & 0.25 & 5.00 & 0.161 & 0.779 & \\
$\ldots$ & $\ldots$ & $\ldots$ & $\ldots$ & $\ldots$ & $\ldots$ & $\ldots$ & \\
\hline
\end{tabular}

\subsection{Modelling by ANN}

In this research, ANN analysis using Feedforward Back Propagation (BP). The ANN model optimization is based on (a) the best training algorithm criteria and (b) the number of neurons in the hidden layer. Before train and testing networks, the normalization of input and target data is in the range of -1 and +1 , with Equation 18.

$$
x_{i}=\frac{2}{\left(d_{\text {max }}-d_{\text {min }}\right)}\left(d_{i}-d_{\text {min }}\right)-1
$$

where, $d_{\max }$ and $d_{\text {min }}$ are the maximum and minimum values of the row data respectively, while $d_{i}$ is the input and output data set.

The best training algorithm criteria are determined based on the type of BP algorithm in the matlab toolbox. Training runs on the default parameters value, and some inputs were specified as follows: 10 neurons in the hidden layer, type of learning were learngd, tansig in hidden and output layer as activation function, the epoch was 1000 and performance goal was MSE/MAPE.

Data for training was selected data-1 to data-28 $(87.5 \%)$ in Table 4 and testing using data-29, data-30, and data in Table 11 (12.5\%).

Table 11 Data for testing

\begin{tabular}{|c|c|c|c|c|c|c|}
\hline \multirow[b]{2}{*}{ No. } & \multicolumn{4}{|c|}{ Independent Variables } & \multirow{2}{*}{$\begin{array}{c}\text { Cutting } \\
\text { Force } \\
F_{C}(\mathrm{~N})\end{array}$} & \multirow{2}{*}{$\begin{array}{c}\text { Surface } \\
\text { Roughness } \\
R_{a}(\mu \mathrm{m})\end{array}$} \\
\hline & $\begin{array}{c}V_{c} \\
\mathrm{~m} / \mathrm{min}\end{array}$ & $\begin{array}{c}\boldsymbol{f}_{\mathbf{z}} \\
\mathrm{mm} / \mathrm{th}\end{array}$ & $\begin{array}{c}\boldsymbol{a}_{r} \\
\mathrm{~mm}\end{array}$ & $\begin{array}{c}\boldsymbol{a}_{\mathrm{x}} \\
\mathrm{mm}\end{array}$ & & \\
\hline 1 & 100 & 0.025 & 0.4 & 10 & 69.26 & 0.210 \\
\hline 2 & 100 & 0.063 & 0.4 & 10 & 57.66 & 0.231 \\
\hline
\end{tabular}

The results of training and testing on different BP algorithms that produce the best MSE/MAPE values for both $F_{c}$ and $R_{a}$ are Levenberg-Marquardt, such as shown in Table 11 and Table 12. Therefore, this algorithm was considered as training and testing.
Table 11 The result of training and testing for cutting force

\begin{tabular}{|c|c|c|c|c|}
\hline \multicolumn{2}{|l|}{ BP Algorithm } & MSE & MAPE & $\mathbf{R}^{2}$ \\
\hline \multirow{2}{*}{ Scaled conjugate } & $a$ & 0.355 & 0.5961 & 0.9992 \\
\hline & $b$ & 203.618 & 17.3214 & 0.9016 \\
\hline \multirow{2}{*}{ Resilient } & a & 0.463 & 1.0515 & 0.9990 \\
\hline & $b$ & 170.973 & 15.2 & 0.9994 \\
\hline \multirow{2}{*}{$\begin{array}{l}\text { Random Weight/Bias } \\
\text { Rule }\end{array}$} & a & 2.610 & 4.3523 & 0.9943 \\
\hline & $b$ & 184.544 & 16.6667 & 0.9988 \\
\hline \multirow{2}{*}{ Levenberg-Marquardt } & 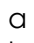 & 1.678 & & 0.9962 \\
\hline & $b$ & 11.428 & 69 & 0.9926 \\
\hline \multirow{2}{*}{ One-step secant } & 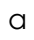 & 2.014 & 3.6307 & 0.9955 \\
\hline & $b$ & 159.848 & 15.9503 & 0.9986 \\
\hline \multirow{2}{*}{$\begin{array}{l}\text { Grad. descent with } \\
\text { momentum and } \\
\text { adapt. learning rate }\end{array}$} & a & 2.045 & 3.6969 & 0.9955 \\
\hline & $b$ & 35. & 3 & 0.9953 \\
\hline \multirow{2}{*}{ gradient descent } & . & 6.477 & 6.9838 & 0.9855 \\
\hline & $b$ & 274.566 & 17. & 0.7096 \\
\hline \multirow{2}{*}{$\begin{array}{l}\text { Gradient descent with } \\
\text { adapting. learning rate }\end{array}$} & a & 5.758 & 5.3274 & 0.9870 \\
\hline & $b$ & 138.283 & 13.6154 & 0.9578 \\
\hline \multirow{2}{*}{ Gradient descent } & a & 75.515 & 16.6541 & 0.8134 \\
\hline & $b$ & 166.656 & 14.6502 & 0.9484 \\
\hline \multirow{6}{*}{$\begin{array}{l}\text { Conjugate grad. with } \\
\text { Polak-Ribiére updates } \\
\text { Conjugate grad. with } \\
\text { Fletc.-Reeves updates } \\
\text { Conjugate grad. with } \\
\text { Powell-Beale restarts }\end{array}$} & a & 0.392 & 1.0125 & 0.9991 \\
\hline & $b$ & 301.184 & 20.1655 & 0.9981 \\
\hline & a & 1.136 & 2.2566 & 0.9975 \\
\hline & $b$ & 177.759 & 16.9 & 0.9922 \\
\hline & a & 0.431 & 19 & 0.9990 \\
\hline & $b$ & 106.568 & 9.3596 & 0.8819 \\
\hline \multirow{2}{*}{ Bayesian regularization } & a & 7.734 & 6.8469 & 0.9831 \\
\hline & $b$ & 172.866 & 13.2503 & 0.8120 \\
\hline \multirow{2}{*}{ BFGS quasi-Newton } & a & 0.354 & 05651 & 0.9992 \\
\hline & 0 & 134.421 & 14.2471 & 0.9153 \\
\hline
\end{tabular}

$a=$ Training and $b=$ Testing

Table 12 The result of training and testing for surface roughness

\begin{tabular}{|c|c|c|c|c|}
\hline \multicolumn{2}{|l|}{ BP Algorithm } & MSE & \multirow{2}{*}{$\begin{array}{l}\text { MAPE } \\
2.0812\end{array}$} & \multirow{2}{*}{$\begin{array}{c}\mathbf{R}^{\mathbf{2}} \\
0.9834\end{array}$} \\
\hline conjugate & $a$ & 0.0000609 & & \\
\hline gradient & & 0.0013506 & 14.1182 & 0.7226 \\
\hline \multirow{2}{*}{ Resilient } & a & 0.0000661 & 62 & 0.9821 \\
\hline & & 0.0005122 & 1 & 0.7036 \\
\hline \multirow[t]{2}{*}{ Random Weight/Bias } & a & 0.0007217 & 8 & 0.8234 \\
\hline & $b$ & 0.0008084 & 11. & 0.6962 \\
\hline \multirow{2}{*}{ Levenberg-Marquardt } & & 0.0000413 & & 0.9888 \\
\hline & V & 0.0004729 & & 0.9540 \\
\hline \multirow{2}{*}{ One-step secant } & 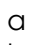 & 817 & 37 & 0.9777 \\
\hline & $b$ & & & \\
\hline \multirow{2}{*}{$\begin{array}{l}\text { Grad. descent with } \\
\text { momentum and } \\
\text { adapt. learning rate }\end{array}$} & a & 728 & & \\
\hline & b & 0.0004718 & 8.0641 & 0.7086 \\
\hline \multirow{2}{*}{ gradient descent } & 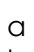 & 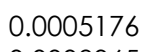 & & \\
\hline & & & & \\
\hline \multirow{2}{*}{$\begin{array}{l}\text { Gradient descent with } \\
\text { adapting. learning rate }\end{array}$} & a & 0.0 & 9 & 0.9416 \\
\hline & r & $0 . c$ & & 0.7 \\
\hline \multirow{2}{*}{ Gradient descent } & a & 0.00 & 10.2 & 0.7502 \\
\hline & $b$ & 0.0 & & 0.7210 \\
\hline \multirow{6}{*}{$\begin{array}{l}\text { Conjugate grad. with } \\
\text { Polak-Ribiére updates } \\
\text { Conjugate grad. with } \\
\text { Fletc.-Reeves updates } \\
\text { Conjugate grad. with } \\
\text { Powell-Beale restarts }\end{array}$} & a & 811 & 52 & 0.9779 \\
\hline & $\mathrm{b}$ & 0.00 & 8 & 0.7263 \\
\hline & a & 0.0000667 & 2.0333 & 0.9818 \\
\hline & $b$ & 0.0004213 & 5.2342 & 0.7225 \\
\hline & a & 0.0002056 & 5.0740 & 0.9431 \\
\hline & $b$ & 0.0011474 & 13.3064 & 0.7230 \\
\hline \multirow{2}{*}{ Bayesian regularization } & & 0.0000806 & 2.8561 & 0.9805 \\
\hline & 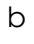 & 0.0004590 & 4.6 & 0.5773 \\
\hline \multirow{2}{*}{ BFGS quasi-Newton } & d & 0.0000413 & 0.9547 & 0.9888 \\
\hline & & 0.0024770 & 15.8320 & 0.6591 \\
\hline
\end{tabular}

$a=$ Training and $b=$ Testing 
The optimum number of neurons in the hidden layer is determined based on the MSE/MAPE after training and testing. There is no standard rule about the number of hidden layers, and it depends on the specifications and complexity of the experimental data. Many researchers only use a hidden layer to obtain optimal conditions [22], [23], [19].

The ANN structure chosen in this study was 4-n-1, where $\mathrm{n}$ is the number of neurons in the hidden layer, as shown in Figure 2. The results of training to obtain the best network performance for the number of neurons 1 to 20 are shown in Figure 3 and Figure 4.

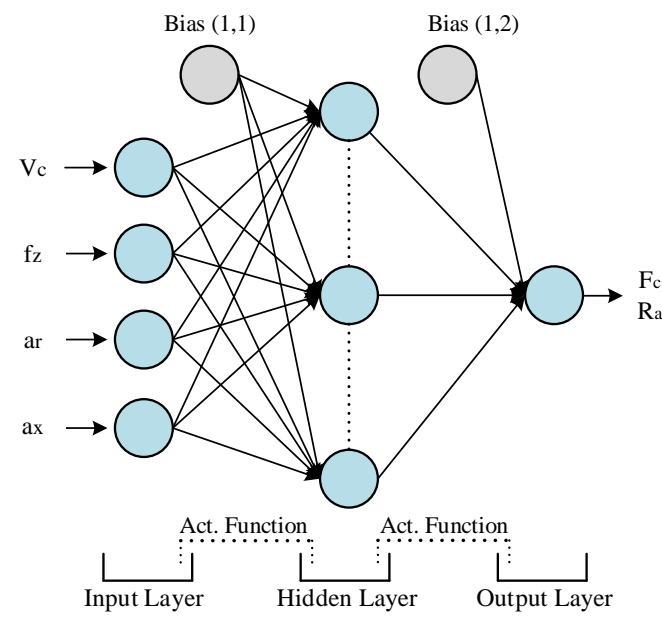

Figure 2 ANN with architecture 4-n-1 ( $n$ is the sum of neuron in the hidden layer
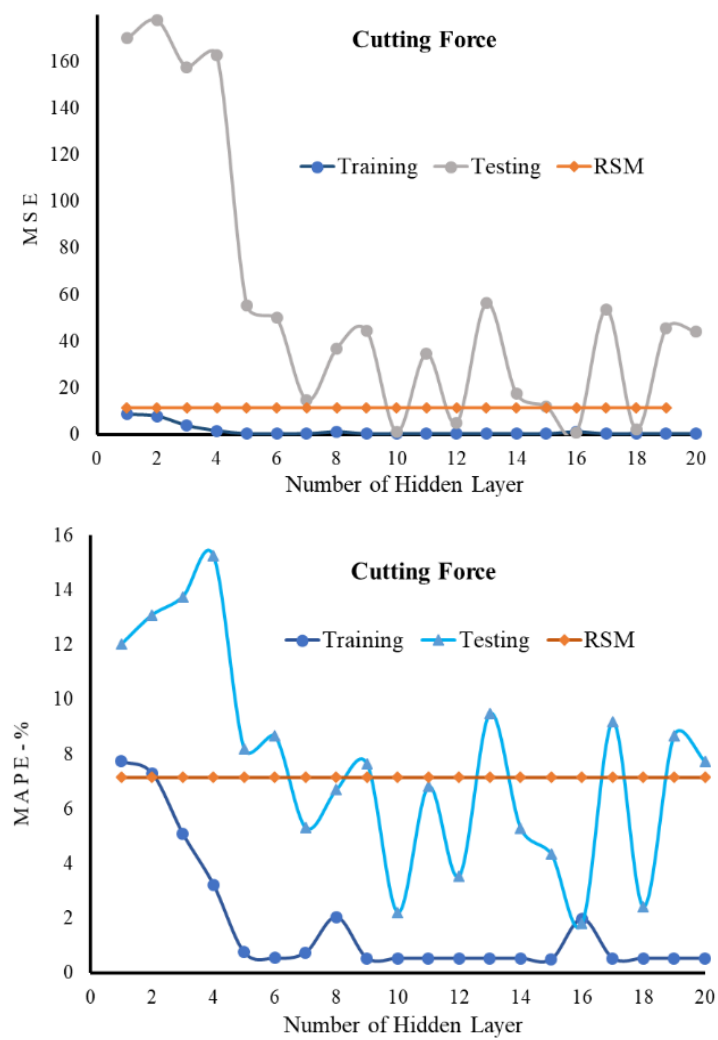

Figure 3 The network's performance in the hidden layer for cutting force
Experimental results and prediction with RSM and ANN are presented in Table 13 and Table 14. It was observed that the range of error percentage RSM is 15.09 to $18.307 \%$ at $F_{c}$ and -35.62 to $22.84 \%$ at $R a$. Error percentage between experiment result and ANN is 6.922 to $7.096 \%$ at $F_{c}$ and -9.198 to $15.202 \%$ at $R_{a}$. From the prediction results between these two models, the percentage error ANN models are significantly better than the RSM model. The developed ANN model can be effectively utilized for prediction of $F_{c}$ and $R_{a}$.
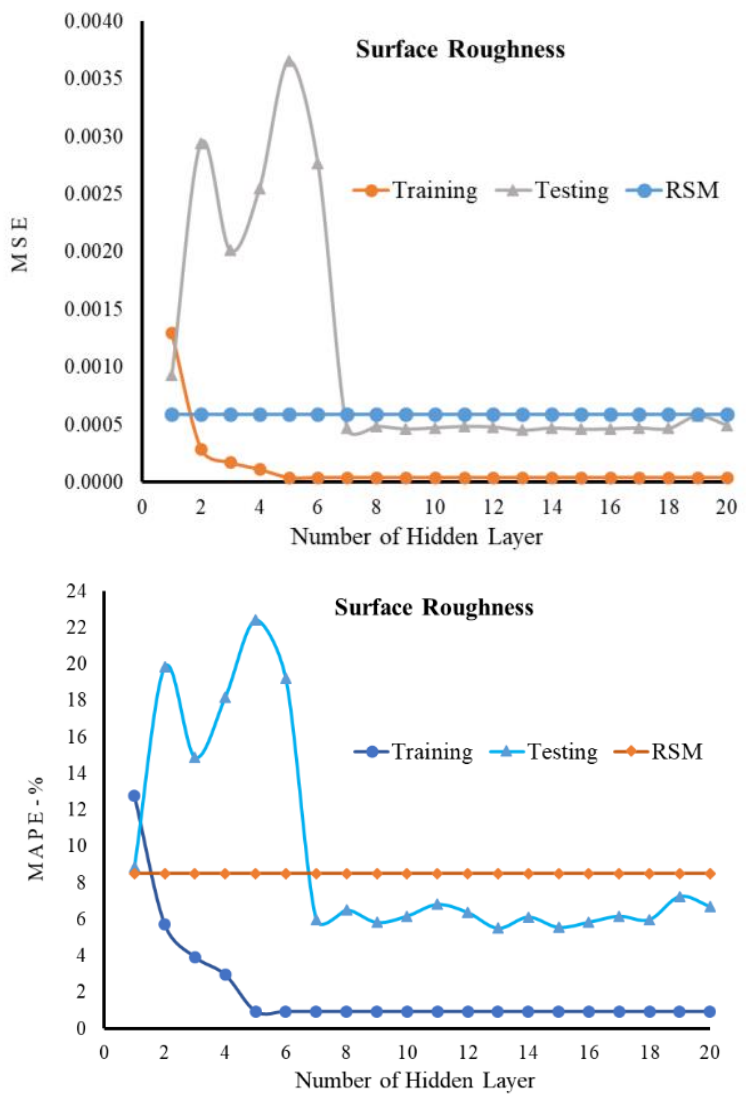

Figure 4 The network's performance in the hidden layer for surface roughness

Table 13 The value of experiment and prediction $\mathrm{F}_{\mathrm{c}}$

\begin{tabular}{cccccc}
\hline N & Average & \multicolumn{2}{c}{ RSM } & \multicolumn{2}{c}{ ANN } \\
\cline { 3 - 6 } O & F $_{\mathbf{c}}$ Exp. (N) & Predicted & \% Error & Predicted & \% Error \\
\hline 1 & 20.689 & 17.936 & 13.30 & 20.689 & 0.000004 \\
2 & 13.983 & 14.805 & -5.88 & 13.984 & -0.008784 \\
3 & 20.614 & 23.024 & -11.69 & 20.614 & -0.000001 \\
4 & 25.616 & 25.069 & 2.14 & 25.616 & -0.000040 \\
5 & 25.085 & 26.786 & -6.78 & 25.085 & 0.000003 \\
6 & 22.916 & 22.253 & 2.89 & 22.916 & 0.000000 \\
7 & 36.112 & 35.548 & 1.56 & 36.112 & 0.000000 \\
8 & 39.173 & 38.956 & 0.55 & 39.173 & 0.000000 \\
9 & 29.798 & 33.151 & -11.25 & 29.798 & 0.000001 \\
10 & 31.244 & 29.719 & 4.88 & 31.244 & 0.000011 \\
11 & 46.511 & 44.846 & 3.58 & 46.511 & 0.000000 \\
12 & 51.180 & 53.033 & -3.62 & 51.18 & 0.000000 \\
13 & 48.152 & 46.068 & 4.33 & 48.152 & 0.000002 \\
14 & 41.959 & 41.566 & 0.94 & 41.959 & 0.000000 \\
15 & 61.658 & 64.430 & -4.50 & 61.658 & -0.000001 \\
16 & 71.003 & 76.686 & -8.00 & 71.002 & 0.000898 \\
17 & 34.918 & 30.326 & 13.15 & 34.918 & 0.000002 \\
\hline
\end{tabular}




\begin{tabular}{cccccc}
\hline N & Average & \multicolumn{2}{c}{ RSM } & \multicolumn{2}{c}{ ANN } \\
\cline { 3 - 6 } o & F $_{\mathbf{c}}$ Exp. (N) & Predicted & \% Error & Predicted & \% Error \\
\hline 18 & 34.050 & 29.064 & 14.64 & 34.05 & -0.000002 \\
19 & 20.478 & 21.837 & -6.64 & 20.478 & 0.000000 \\
20 & 54.520 & 58.332 & -6.99 & 54.52 & -0.000003 \\
21 & 24.415 & 22.200 & 9.07 & 24.415 & 0.000000 \\
22 & 53.338 & 53.906 & -1.06 & 53.338 & -0.000001 \\
23 & 17.439 & 18.307 & -4.98 & 17.439 & 0.000000 \\
24 & 66.817 & 76.901 & -15.09 & 66.817 & 0.000001 \\
25 & 33.707 & 27.562 & 18.23 & 31.315 & 7.095716 \\
26 & 29.288 & 27.562 & 5.89 & 31.315 & -6.921767 \\
27 & 31.062 & 27.562 & 11.27 & 31.315 & -0.815296 \\
28 & 31.204 & 27.562 & 11.67 & 31.315 & -0.356516 \\
29 & 30.240 & 27.562 & 8.85 & 31.315 & -3.555711 \\
30 & 31.762 & 27.562 & 13.22 & 31.315 & 1.406564 \\
\hline
\end{tabular}

Table 14 The value of experiment and prediction $\mathrm{Ra}$

\begin{tabular}{cccccc}
\hline N & Average & \multicolumn{2}{c}{ RSM } & \multicolumn{2}{c}{ ANN } \\
\cline { 3 - 6 } o & Ra Exp. (N) & Predicted & \% Error & Predicted & \% Error \\
\hline 1 & 0.223 & 0.214 & 3.85 & 0.223 & -0.000001 \\
2 & 0.187 & 0.160 & 14.69 & 0.187 & -0.000003 \\
3 & 0.283 & 0.283 & 0.06 & 0.283 & 0.000000 \\
4 & 0.183 & 0.209 & -14.40 & 0.183 & 0.000000 \\
5 & 0.190 & 0.198 & -4.37 & 0.190 & 0.000001 \\
6 & 0.176 & 0.188 & -6.68 & 0.176 & 0.000001 \\
7 & 0.255 & 0.271 & -6.27 & 0.255 & 0.000003 \\
8 & 0.270 & 0.255 & 5.46 & 0.270 & 0.000003 \\
9 & 0.187 & 0.197 & -5.53 & 0.187 & -0.000003 \\
10 & 0.190 & 0.178 & 6.36 & 0.190 & -0.000001 \\
11 & 0.297 & 0.277 & 6.72 & 0.297 & 0.000000 \\
12 & 0.260 & 0.248 & 4.43 & 0.260 & 0.000000 \\
13 & 0.220 & 0.191 & 13.01 & 0.220 & 0.000005 \\
14 & 0.220 & 0.220 & 0.19 & 0.220 & 0.000011 \\
15 & 0.238 & 0.278 & -16.94 & 0.238 & 0.000000 \\
16 & 0.307 & 0.318 & -3.49 & 0.307 & 0.001234 \\
17 & 0.282 & 0.258 & 8.40 & 0.282 & 0.000001 \\
18 & 0.223 & 0.214 & 4.17 & 0.223 & 0.000001 \\
19 & 0.120 & 0.163 & -35.62 & 0.120 & -0.003927 \\
20 & 0.288 & 0.222 & 22.84 & 0.288 & 0.000002 \\
21 & 0.195 & 0.212 & -8.87 & 0.195 & -0.000002 \\
22 & 0.275 & 0.237 & 13.70 & 0.275 & 0.000003 \\
23 & 0.235 & 0.223 & 5.03 & 0.235 & 0.000000 \\
24 & 0.253 & 0.255 & -0.81 & 0.253 & 0.000001 \\
25 & 0.220 & 0.227 & -3.03 & 0.231 & -5.227273 \\
26 & 0.238 & 0.227 & 4.76 & 0.231 & 2.731093 \\
27 & 0.212 & 0.227 & -6.92 & 0.231 & -9.198113 \\
28 & 0.256 & 0.227 & 11.46 & 0.231 & 9.570313 \\
29 & 0.273 & 0.227 & 16.97 & 0.231 & 15.20147 \\
30 & 0.228 & 0.227 & 0.58 & 0.231 & -1.535088 \\
\hline & & & & &
\end{tabular}

3.3 The Effect of Independent Variables Toward Dependent Variables

Figure 5 shows the perturbation plot between Independent and dependent variables for cutting force and surface roughness. It was clear that with the increase of feed (B), DOC radial (C) and DOC axial (C), dependent variables increased due to an increase in the cross-sectional area of the chip. The opposite phenomenon, an increase of cutting speed (A) resulted in a decrease of dependent variables $\left(F_{c}\right.$ and $R_{a}$ ). Usually, the cutting temperature increases with increasing cutting speed and causes a decrease in hardness in the tool contact area of the workpiece, thereby reducing cutting energy. This effect causes a reduction in the cutting force and surface of the workpiece to be smooth [24]. The impact of B, C, D on cutting force was more significant than surface roughness.
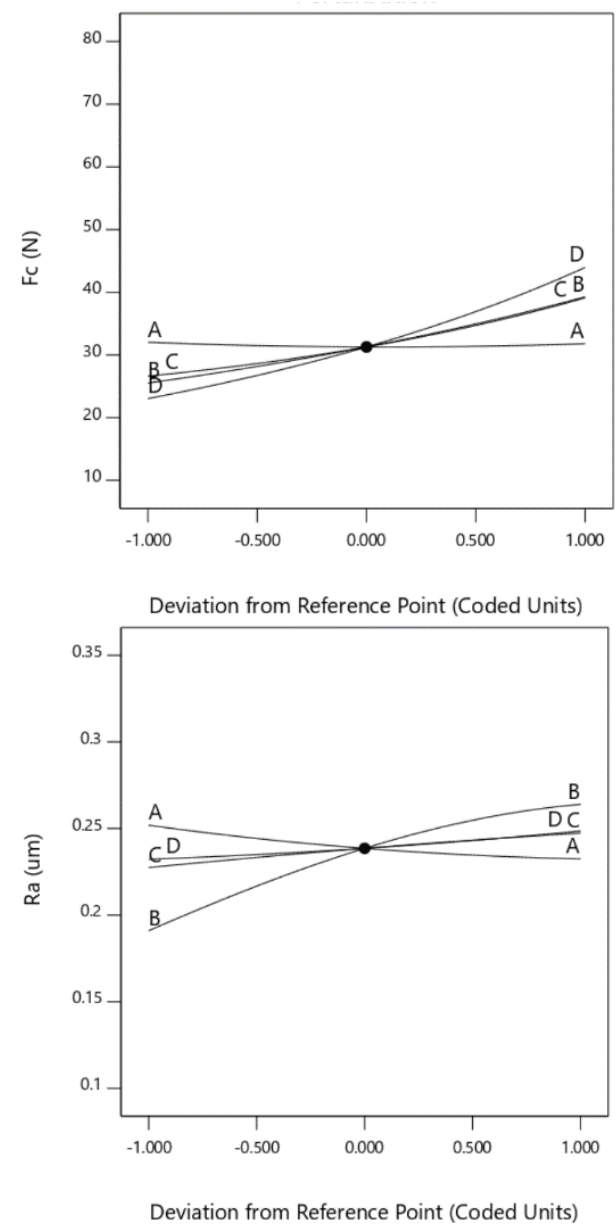

Figure 5 Perturbations plot for cutting force and surface roughness

\subsection{CONCLUSION}

The application of the RSM and the ANN for optimum performance on end milling thin walled Ti6Al4V has been presented in this paper. The result of the analysis has shown that the second order RSM models and Levenberg-Marquardt algorithm in the ANN network were developed to predict the $F_{c}$ and $R_{a}$ values from experimental data. The prediction data by RSM and ANN are very close to the data obtained from the experimental results. The training and testing results of network structure 4-10-1 for $F_{c}$ and 4-13-1 for Ra shows better accuracy than RSM predictions.

From the development of the model shows that the $f_{z}$ cause the most significant effect on $F_{c}$ and $R_{a}$, followed by $a_{x}$ and $a_{r}$. And contrary to the influence of the $V_{c}$ where the increase of the $V_{c}$ reduced $F_{c}$ and $R a$. The optimum condition was determined based on the minimum value of $F_{c}$ and $R_{a}$ on the independent 
variable range. Optimum condition at $V_{c}=125 \mathrm{~m} / \mathrm{min}$, $f_{z}=0.04 \mathrm{~mm} /$ tooth,$a_{r}=0.25 \mathrm{~mm}$ and $a_{a}=5 \mathrm{~mm}$ which resulted $F_{c}$ and $R_{a}$ were $14.89 \mathrm{~N}$ and $0.161 \mu \mathrm{m}$, respectively.

\section{Acknowledgment}

The authors wish to thank Sriwijaya University (Unsri) and Universiti Teknologi Malaysia (UTM) for the cooperation and assistance under the research collaboration between both universities. Special appreciation to the Research Management Centre of UTM for the financial support through the RUG funding Q.J130000.2409.04G39.

\section{References}

[1] Bolar, G., Das, A., and Joshi, S. N. 2018. Analysis of Surface Integrity and Dimensional Accuracy During Thin-Wall Machining BT - Techno-Societal 2016. In: Pawar, P. M. Ronge, B. P., Balasubramaniam, R., Seshabhattar, S., editors. Proceedings of the International Conference on Advanced Technologies for Societal Applications, TechnoSocietal 2016. Cham: Springer International Publishing. 681-

[2] Huang, P. L., Li, J. F., Sun, J., and Jia, X. M. 2016. Cutting Signals Analysis in Milling Titanium Alloy Thin-part Components and Non-thin-wall Components. International Journal of Advanced Manufacturing Technology 84(9): 2461-9. Doi: 10.1007/s00170-015-7837-0.

[3] Feng, J., Sun, Z., Jiang, Z., and Yang, L. 2016. Identification of Chatter in Milling of Ti-6Al-4V Titanium Alloy Thin-walled Workpieces based on Cutting Force Signals and Surface Topography. International Journal of Advanced Manufacturing Technology 82(9-12): 1909-20. Doi: 10.1007/s00170-015-7509-0.

[4] Jiang, Z. H., Jia, M. F., and Liu, P. H. 2017. Experimental Study on Milling Force in Processing Ti6Al4V Thin-walled Part 154(Icmia). 486-515.

[5] Park, K.-H., Suhaimi, M. A., Yang, G.-D., Lee, D.-Y., Lee, S.W., and Kwon, P. 2017. Milling of Titanium Alloy with Cryogenic Cooling and Minimum Quantity Lubrication (MQL). International Journal of Precision Engineering and Manufacturing. 18(1): 5-14. Doi: 10.1007/s12541-017-0001-z.

[6] Srikant, R. R. and Rao, P. N. 2017. Use of Vegetable-based Cutting Fluids for Sustainable Machining. Doi: 10.1007/9783-319-51961-6.

[7] Huang, Y. A., Zhang, X., and Xiong, Y. 2012. Finite Element Analysis of Machining Thin-Wall Parts: Error Prediction and Stability Analysis. In: Ebrahimi, F., editor. Finite Element Analysis-Applications in Mechanical Engineering. 1st ed. In Tech. 327-54.

[8] Debnath, S., Reddy, M. M., and Yi, Q. S. 2014. Environmental Friendly Cutting Fluids and Cooling Techniques in Machining: A Review. Journal of Cleaner Production 83(November): 33-47. Doi: 10.1016/j.jclepro.2014.07.071.

[9] Boswell, B., Islam, M. N., Davies, I. J., Ginting, Y. R., and Ong, A. K. 2017. A Review Identifying the Effectiveness of Minimum Quantity Lubrication (MQL) During Conventional Machining. International Journal of Advanced Manufacturing Technology. Feb.: 1-20. Doi: 10.1007/s00170017-0142-3.

[10] Sharif, M. N., Pervaiz, S., and Deiab, I. 2017. Potential of Alternative Lubrication Strategies for Metal Cutting Processes: A Review. International Journal of Advanced Manufacturing Technology. Doi: 10.1007/s00170-016-9298-
5 .

[11] Sharma, V. S. S., Singh, G., and Sørby, K. 2015. A Review on Minimum Quantity Lubrication for Machining Processes Machining Processes. Machining Science and Technology 30(8): 935-53. Doi: 10.1080/10426914.2014.994759.

[12] Sodavadia, K. P. and Makwana, A. H. 2014. Experimental Investigation on the Performance of Coconut oil Based Nano Fluid as Lubricants during Turning of AISI 304 Austenitic Stainless Steel. International Journal of Advanced Mechanical Engineering. 4(1): 55-60.

[13] Rahim, E. A. and Sasahara, H. 2011. Investigation of Tool Wear and Surface Integrity on MQL Machining of Ti-6AL-4V using Biodegradable Oil. Proceeding of the Institution of Mechanical Engineers, Part B: Journal of Engineering Manufacture 225(9): 1505-10. Doi: $10.1177 / 0954405411402554$.

[14] Armendia, M., Garay, A., Iriarte, L., and Arrazola, P. 2010. Comparison of the Machinabilities of Ti6AI4V and TIMETAL ( $54 \mathrm{M}$ using Uncoated WC - Co Tools. Journal of Materials Processing Technology. 210: 197-203. Doi: 10.1016/j.jmatprotec.2009.08.026.

[15] Rahman Rashid, R. A., Palanisamy, S., Sun, S., and Dargusch, M. S. 2016. Tool Wear Mechanisms Involved in Crater Formation on Uncoated Carbide Tool when Machining Ti6Al4V Alloy. International Journal of Advanced Manufacturing Technology. 83(9-12): 1457-65. Doi: 10.1007/s00170-015-7668-z.

[16] Bolar, G. and Joshi, S. N. 2017. Three-dimensional Numerical Modeling, Simulation and Experimental Validation of Milling of a Thin-wall Component. Proceedings of the Institution of Mechanical Engineers, Part B: Journal of Engineering Manufacture. $231(5): \quad 792-804 . \quad$ Doi: $10.1177 / 0954405416685387$.

[17] Rao, R. V. and Kalyankar, V. D. 2014. Optimization of Modern Machining Processes using Advanced Optimization Techniques: A Review. The International Journal of Advanced Manufacturing Technology. 1159-88. Doi: 10.1007/s00170-014-5894-4.

[18] Myers, R. H., Montgomery, D. C., and Anderson-Cook, C. M. 2009. Response Surface Methodology: Process and Product Optimization Using Designed Experiments. 3rd ed. Hoboken, New Jersey (USA), United States of America (USA): John Wiley \& Sons, Inc.

[19] Mohruni, A. S., Yanis, M., Sharif, S., Yani, I., Yuliwati, E., Ismail, A.F., et al. 2017. A Comparison RSM and ANN Surface Roughness Models in Thin-wall Machining of Ti6Al4V using Vegetable Oils under MQL-condition. AIP Conference Proceedings 1885(020161): 1-10. Doi: 10.1063/1.5002355.

[20] Kilickap, E., Yardimeden, A., and Çelik, Y. H. 2017. Mathematical Modelling and Optimization of Cutting Force, Tool Wear and Surface Roughness by using Artificial Neural Network and Response Surface Methodology in Milling of Ti-6242S. Applied Sciences. 7(10): 1064. Doi: 10.3390/app7101064.

[21] Sangwan, K. S., Saxena, S., and Kant, G. 2015. Optimization of Machining Parameters to Minimize Surface Roughness using Integrated ANN-GA Approach. Procedia CIRP 29: 305-10. Doi: 10.1016/j.procir.2015.02.002.

[22] Kant, G. and Sangwan, K. S. 2015. Predictive Modelling and Optimization of Machining Parameters to Minimize Surface Roughness using Artificial Neural Network Coupled with Genetic Algorithm. Procedia CIRP 31 (CIRP 15): 453-8. Doi: 10.1016/j.procir.2015.03.043

[23] Sehgal, A. K. 2014. Application of Artificial Neural Network in Surface Roughness Prediction considering Mean Square Error as Performance Measure. 72-6.

[24] Ozel, T., Thepsonthi, T., Ulutan, D., Kaftanoglu, B. 2011. Experiments and Finite Element Simulations on Micro-Milling of Ti-6Al-4V Alloy with Uncoated and CBN Coated MicroTools. CIRP Ann Manuf Technol. 60: 85-88. Doi: 10.1016/j.cirp.2011.03.087. 